\title{
SIFAT-SIFAT TANAH YANG BERKEMBANG DARI BAHAN VOLKAN DI HALMAHERA BARAT, MALUKU UTARA
}

\author{
Hikmatullah \\ Balai Besar Litbang Sumberdaya Lahan Pertanian (BBSDLP) \\ Jl. Ir. H. Juanda No. 98, Bogor 16123 \\ hkmt_2006@yahoo.co.id
}

\begin{abstract}
[SOIL PROPERTIES DEVELOPED FROM VOLCANIC MATERIALS IN WEST HALMAHERA, NORTH MALUKU]. West Halmahera region is dominated by soils formed from young volcanic materials that have unique properties and high productivity for agricultural use. The purpose of this study is to characterize soil properties derived from volcanic materials in that area and to test the andic soil properties according to Soil Taxonomy 2006. Four pedons of strato volcanoes from the area were described their morphological properties in the field and 16 soil samples were analyzed for physical, chemical and mineralogical properties in the laboratory. The results indicated that all the pedons show black to very dark brown colored in A horizons and dark brown to brown in B horizons. The soils are deep, loam to sandy loam texture (sand content 38-71\%). The soils have weak to moderate subangular blocky structure and very friable consistency. The soils show slightly acid to neutral reaction $\left(\mathrm{pH}_{\mathrm{H} 2 \mathrm{O}}\right.$ 6.0-6.8), high $\mathrm{pH}_{\mathrm{NaF}}(10.78-10.95)$, high organic carbon (3.75-4.65\%) in A horizon, moderate to high cation exchange capacity and base saturation. All the pedons show high P-retentions (45-80 \%), high values of ammonium oxalate extractable $\left(\mathrm{Al}_{\mathrm{o}}+0.5 \mathrm{Fe}_{\mathrm{o}}\right)(2.91-6.070 \%)$, high volcanic glass content $(>5 \%)$, and index values of $\left[\left(\mathrm{Al}_{\mathrm{o}}+0,5 \mathrm{Fe}_{\mathrm{o}}\right) \times 15,625+(\%\right.$ volcanic glass $\left.)\right] \geq 36.25$ that meet the requirements for andic soil properties, and thus they are classified as Andisols order. The sand minerals are dominated by volcanic glasses and dark minerals that belong to intermediary properties, and high weatherable mineral reserve.
\end{abstract}

Keyword: Andisols, andic soil properties, volcanic materials, North Maluku.

\begin{abstract}
ABSTRAK
Wilayah Halmahera Barat didominasi oleh tanah-tanah yang berkembang dari bahan volkan muda dengan sifat-sifat yang unik dan produktivitas yang tinggi untuk pertanian. Tujuan penelitian adalah untuk mempelajari sifat-sifat tanah yang berkembang dari bahan volkan di wilayah tersebut dan menguji sifat-sifat andik menurut Soil Taxonomy 2006. Sebanyak empat pedon tanah volkan pada kerucut volkan dari wilayah kabupaten tersebut telah dideskripsi sifat-sifat morfologinya di lapangan dan sebanyak 16 contoh tanah telah dianalisis sifat-sifat fisik-kimia dan mineral pasirnya di laboratorium. Hasil penelitian menunjukkan bahwa horison A berwarna coklat gelap dan horison B coklat tua. Penampang tanah dalam, tekstur lempung sampai lempung berpasir (kadar pasir 38-71 \%). Struktur lemah dan gumpal bersudut dengan konsistensi gembur sampai sangat gembur. Reaksi tanah agak masam sampai netral $\left(\mathrm{pH}_{\mathrm{H} 2 \mathrm{O}}\right.$ 6.0-6.8), $\mathrm{pH}_{\mathrm{NaF}}$ tinggi (10.78-10.95), kadar $\mathrm{C}$ organik tinggi (3.75-4.65 \%) di horison A, kapasitas tukar kation tanah dan kejenuhan basa sedang sampai tinggi. Semua pedon mempunyai retensi $\mathrm{P}$ cukup tinggi $(45-80 \%), \mathrm{kadar}\left(\mathrm{Al}_{\mathrm{o}}+0.5 \mathrm{Fe} \mathrm{o}_{\mathrm{o}}\right)$ ekstraksi amonium oksalat tinggi (2.91-6.07 \%), kadar gelas volkan tinggi (20-46\%), dan nilai indeks $\left[\left(\mathrm{Al}_{\mathrm{o}}+0.5 \mathrm{Fe} \mathrm{o}_{\mathrm{o}}\right) \mathrm{x}\right.$ $15.625+(\%$ gelas volkan $)] \geq 36.25$, yang memenuhi persyaratan sifat andik, sehingga diklasifikasikan sebagai ordo Andisols. Mineral fraksi pasir didominasi oleh gelas volkan dan mineral kelam yang bersifat intermedier dengan cadangan mineral tinggi.
\end{abstract}

Kata kunci: Andisols, sifat-sifat andik, bahan volkan, Maluku Utara 


\section{PENDAHULUAN}

Tanah-tanah yang berkembang dari bahan volkan muda, mempunyai peranan sangat penting dalam bidang pertanian karena mempunyai sifat-sifat morfologi, fisik-kimia dan mineral yang unik dan produktivitas yang tinggi untuk pertanian. Tanahtanah tersebut umumnya diklasifikasikan sebagai ordo Andisols, tergantung pada tingkat pelapukan dan proses pembentukan tanahnya (Shoji et al., 1993). Hasil-hasil penelitian tanah-tanah dari bahan volkan muda telah banyak dilaporkan dari berbagai negara, seperti dari Jepang (Shoji dan Ono, 1978), Amerika Serikat (Wada et al., 1986; Shoji et al., 1988), Mexico (Prado et al., 2007), Ekuador (Buytaert et al., 2006), Costa Rica (Nieuwenhuyse et al., 1993), Selandia Baru (Parfitt et al., 1983), Portugal (Madeira et al., 1994), dan Rwanda (Nizeyimana, 1997).

Di Indonesia, ordo Andisols luasnya diperkirakan sekitar 5.4 juta ha atau $2.9 \%$ dari luas daratan Indonesia (Subagyo et al., 2000), sedangkan di dunia diperkirakan $0.84 \%$ dari luas daratan muka bumi (Leamy, 1984). Tanah-tanah volkan banyak tersebar di Sumatera, Jawa, Bali, Nusa Tenggara, Sulawesi Selatan, Sulawesi Utara dan Halmahera. Penelitian tanah-tanah dari bahan volkan di Indonesia telah dirintis antara lain oleh Van Schuylenborgh (1957), Dudal dan Soepraptohardjo (1960), dan Tan (1965). Beberapa hasil penelitian tanah-tanah volkan dalam dekade terakhir telah dilaporkan antara lain dari Sumatera (Fiantis dan Van Ranst, 1997; Alkasuma dan Badayos, 2003), Jawa (Arifin dan Hardjowigeno, 1997; Subagjo et al., 1997; Van Ranst et al., 2002; Yatno dan Zauyah, 2008), Sulawesi Utara (Hikmatullah, 2008), P. Sumbawa (Sukarman et al., 1993), dan P. Flores (Hikmatullah et al., 2003).

Andisols umumnya berwarna gelap terutama di lapisan atas, kadar bahan organik tinggi, bersifat smeary, berat isi rendah, porositas tinggi, retensi fosfat tinggi, kadar $\mathrm{Al}_{\mathrm{o}}, \mathrm{Fe}_{\mathrm{o}}$ dan $\mathrm{Si}_{\mathrm{o}}$ (ekstraksi amonium oksalat) tinggi (Shoji et al., 1993). Andisols umumnya dijumpai di dataran tinggi (>700 $\mathrm{m}$ dpl.) tetapi bisa juga dijumpai di dataran rendah, seperti di Sumatera Utara dan Sumatera Barat (Tan, 1998). Menurut Soil Survey Staff (2006) ordo Andisols adalah tanah-tanah yang mempunyai sifat andik, yang ditentukan oleh parameter kadar fraksi pasir, berat isi, retensi fosfat, kadar $\left(\mathrm{Al}_{\mathrm{o}}+0.5 \mathrm{Fe}_{\mathrm{o}}\right)$, dan kadar gelas volkan.

Wilayah Kabupaten Halmahera Barat didominasi oleh bahan volkan muda dari beberapa kerucut volkan (Supriatna, 1990), tetapi dari hasil penulusuran pustaka, penelitian tanah-tanah volkan di wilayah tersebut masih sangat sedikit. Tujuan penelitian adalah untuk mempelajari sifat-sifat morfologi, fisik-kimia dan mineralogi tanah-tanah yang berkembang dari bahan volkan muda di wilayah tersebut dan menguji sifat-sifat andik menurut Soil Survey Staff (2006).

\section{METODE PENELITIAN}

Wilayah Kabupaten Halmahera Barat dengan luas sekitar 254,300 ha terletak pada koordinat $00^{\circ}$ $45^{\prime}-01^{\circ} 55^{\prime}$ Lintang Utara dan $127^{\circ} 22^{\prime}-127^{\circ} 54^{\prime}$ Bujur Timur dengan ketinggian tempat 0-1,500 m dari permukaan laut (Gambar 1). Penelitian tanah di lapangan dilakukan pada bulan September 2006.

Data curah hujan yang diwakili oleh stasiun pengamat Jailolo ( $8 \mathrm{~m} \mathrm{dpl}$.) menunjukkan rata-rata tahunan sebesar 2,674 $\mathrm{mm}$ dengan nilai tertinggi $376 \mathrm{~mm}$ (Mei) dan terendah $132 \mathrm{~mm}$ (November). Suhu udara rata-rata bulanan berkisar antara 26.3-26.9 ${ }^{\circ} \mathrm{C}$. Menurut Schmidt dan Ferguson (1951) daerah penelitian termasuk beriklim tropik basah dengan tipe hujan A. Prediksi neraca air dengan program Newhall Simulation Model (Van

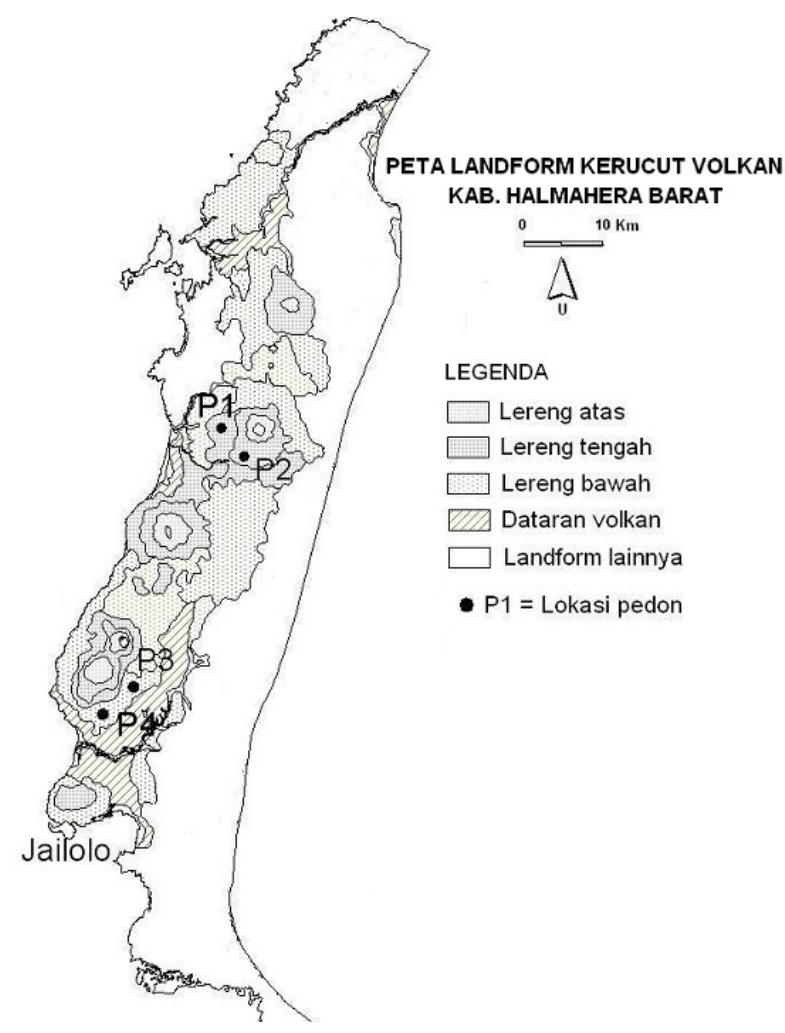

Gambar 1. Peta lokasi dan landform kerucut volkan di Halmahera Barat 
Wambeke et al., 1986) menunjukkan daerah penelitian termasuk rejim kelembaban tanah $u d i k$ dan rejim suhu tanah isohipertermik, dengan periode surplus hampir sepanjang tahun (Gambar 2).

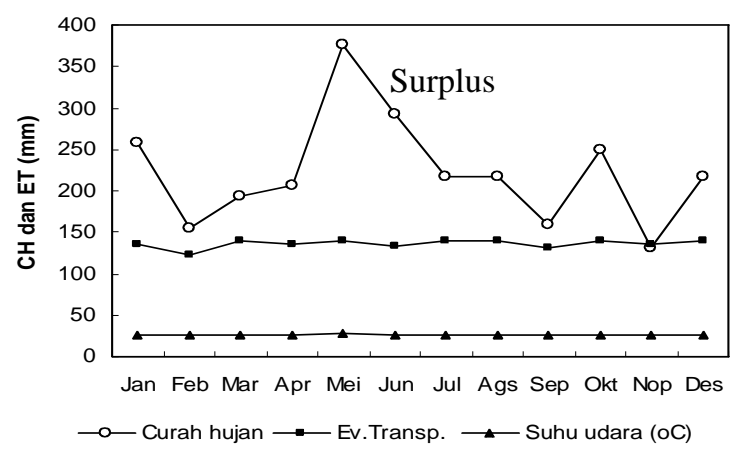

Gambar 2. Neraca air di daerah penelitian

Pulau Halmahera bagian utara didominasi oleh kegiatan volkanisme berumur Kuarter. Beberapa kerucut volkan muda yang masih aktif antara lain G. Gamkonora, G. Sahu, G. Jailolo, dan G. Ibu. Erupsi bahan volkan tersebut bersusunan abu, tuf, lava dan breksi yang bersifat andesitik (Supriatna, 1990). Menurut Van Bemmelen (1970) gunungapi tersebut merupakan hasil aktivitas gunungapi bawah laut (submarine) yang bahan erupsinya bersifat andesitik dan dasitik.

Sebanyak empat pedon pada posisi landform kerucut volkan lereng tengah dan lereng bawah telah diteliti sifat-sifat morfologinya di lapangan, dan sebanyak 16 contoh tanah dari masing-masing horison pedon tersebut telah dianalisis sifat-sifatnya di laboratorium. Lokasi keempat pedon tersebut disajikan pada Gambar 1.

Analisis contoh tanah meliputi penetapan tekstur 3 fraksi (pasir, debu dan liat) dengan metode pipet, berat isi (BD) pada retensi $33 \mathrm{kPa}$, dan kadar air pada retensi $1500 \mathrm{kPa}$. Penetapan sifat kimia tanah meliputi $\mathrm{pH}-\mathrm{H}_{2} \mathrm{O}$ (rasio 1:2.5), kandungan $\mathrm{C}$ organik dengan metode Walkley dan Black, kandungan basa-basa dapat ditukar $(\mathrm{Ca}, \mathrm{Mg}, \mathrm{K}$ dan $\mathrm{Na}$ ) dan kapasitas tukar kation (KTK) tanah dalam ekstraksi amonium asetat $\mathrm{pH}$ 7.0. Untuk mengetahui kandungan bahan amorf dan sifat-sifat andik ditetapkan $\mathrm{pH}-\mathrm{NaF}$ (rasio 1:50), retensi fosfat, kadar $\mathrm{Al}_{\mathrm{o}}$ dan $\mathrm{Fe}_{\mathrm{o}}$ (ekstraksi amonium oksalat) dengan metode Blakemore et al. (1987). Prosedur analisis contoh tanah mengikuti petunjuk dalam Soil Survey Laboratory Method Manual (Burt, 2004). Komposisi mineral fraksi pasir total ditetapkan dengan metode line counting menggunakan mikroskop polarisasi (Buurman, 1990). Klasifikasi tanah ditetapkan menurut sistem Soil Taxonomy (Soil Survey Staff, 2006) sampai tingkat subgrup.

\section{HASIL DAN PEMBAHASAN}

\section{Sifat morfologi tanah}

Sifat morfologi yang menonjol pada tanah-tanah dari bahan volkan di daerah penelitian adalah bahwa semua pedon yang diteliti mempunyai penampang cukup dalam $(>100 \mathrm{~cm})$ dengan ketebalan horison A bervariasi dari 14-35 $\mathrm{cm}$ dan horison B lebih dari $75 \mathrm{~cm}$ (Tabel 1). Horison A berwarna gelap/ hitam (10YR2/1) sampai coklat sangat tua (10YR2/2), sedangkan di horison B warna tanah sedikit agak lebih cerah menjadi coklat sangat tua (10YR2/2) sampai coklat (10YR3/2-3/4). Warna tanah di horison A lebih gelap daripada di horison $\mathrm{B}$, karena pengaruh kandungan bahan organik yang lebih tinggi di horison A. Keempat pedon mempunyai susunan horison A-Bw-C yang menunjukkan tanah dalam tahapan awal perkembangan profil.

Sifat morfologi lain adalah struktur dan konsistensi tanah. Horison A dan B pada semua pedon umumnya mempunyai tingkat perkembangan struktur lemah sampai cukup, dengan bentuk gumpal bersudut yang mudah pecah bila ditekan, dan konsistensi sangat gembur sampai gembur pada kondisi lembab. Sifat-sifat tanah demikian cukup menguntungkan karena tanah akan mudah untuk diolah dan perakaran tanaman akan berkembang dengan baik. Sifat smeary atau rasa licin yang menjadi salah satu indikator tingginya kandungan bahan amorf tidak teridentifikasi pada semua pedon. Hal ini diduga karena kandungan pasir yang cukup tinggi dan belum banyak melapuk.

\section{Sifat fisik tanah}

Tekstur tanah pada semua pedon bervariasi dari lempung sampai lempung berpasir, yang termasuk kedalam kelas sedang (Soil Survey Division Staff, 1993). Sebaran kadar pasir pada semua pedon cukup tinggi dengan variasi antara 40-71\% di horison A, dan antara 43-67 \% di horison B. Sebaliknya kadar liat rendah dengan variasi antara 7-27 \% di horison A dan antara 5-29 \% di horison B. Tanah-tanah volkan dengan kandungan pasir tinggi tersebut serupa dengan bahan volkan yang dijumpai di Sulawesi Utara (Hikmatullah, 2008) dan Pulau Flores (Hikmatullah et al., 1999; Hikmatullah et al., 2003). Tingginya kadar pasir tersebut mencerminkan tingkat pelapukan bahan volkan yang masih rendah atau dalam tahap awal. 


\section{HIKMATULLAH}

Tabel 1. Sifat-sifat morfologi dan fisika dari pedon-pedon di daerah penelitian

\begin{tabular}{|c|c|c|c|c|c|c|c|c|c|c|}
\hline \multirow{2}{*}{ Pedon } & \multirow{2}{*}{ Horison } & \multirow{2}{*}{ Dalam } & \multirow{2}{*}{$\begin{array}{l}\text { Warna } \\
\text { lembab }\end{array}$} & \multirow{2}{*}{ Struktur $^{1)}$} & \multirow{2}{*}{$\begin{array}{c}\text { Konsistensi } \\
\text { lembab }\end{array}$} & \multicolumn{3}{|c|}{ Tekstur } & \multirow{2}{*}{$\begin{array}{l}\text { Berat isi } \\
\text { (BD) }\end{array}$} & \multirow{2}{*}{$\begin{array}{l}\text { Kadar } \\
\text { air }^{3}\end{array}$} \\
\hline & & & & & & Pasir Debu & Liat & Kelas $^{2)}$ & & \\
\hline
\end{tabular}

Lereng tengah; elevasi $360 \mathrm{~m}$ dpl.; lereng 13\%; hutan dan semak belukar; Kec. Ibu

$\begin{array}{cccccccccccc}\text { P1 } & \text { A } & 0-35 & 10 Y R 2 / 2 & 1 . f . s b & \text { Sgt gembur } & 71 & 22 & 7 & \text { SL } & 0,96 & 8,7 \\ & \text { Bw1 } & 35-60 & 10 Y R 3 / 3 & 2 . m . s b & \text { Sgt gembur } & 67 & 28 & 5 & \text { SL } & 0,89 & 8,9 \\ \text { Bw2 } & 60-95 & 10 Y R 3 / 4 & 1 . f . g r & \text { Gembur } & 46 & 44 & 10 & \text { L } & - & \\ & \text { 2C } & 95-140 & 10 Y R 3 / 4 & 1 . f . s b & \text { Gembur } & 49 & 38 & 13 & \text { L } & -\end{array}$

Lereng tengah; elevasi $320 \mathrm{~m}$ dpl.; lereng 6\%; semak belukar; Kec. Ibu

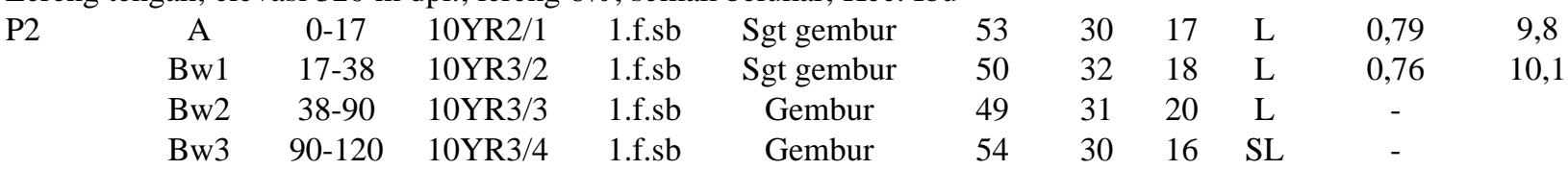

Lereng bawah; elevasi $200 \mathrm{~m}$ dpl.; lereng 13\%; hutan, kebun campuran; Kec. Sahu

\begin{tabular}{|c|c|c|c|c|c|c|c|c|c|c|}
\hline \multirow[t]{4}{*}{ P3 } & $0-17$ & $10 \mathrm{YR} 2 / 1$ & 1.f.sb & Sgt gembur & 46 & 35 & 19 & $\mathrm{~L}$ & 0,82 & 9,9 \\
\hline & $17-45$ & $10 \mathrm{YR} 2 / 2$ & 2.f.sb & Gembur & 43 & 28 & 29 & SCL & 0,83 & 11,8 \\
\hline & $45-90$ & $10 \mathrm{YR} 3 / 4$ & 1.f.sb & Gembur & 56 & 22 & 22 & SCL & - & \\
\hline & $90-120$ & $10 \mathrm{YR} 3 / 4$ & 1.f.sb & Gembur & 48 & 36 & 16 & $\mathrm{~L}$ & - & \\
\hline \multicolumn{11}{|c|}{ Lereng bawah; elevasi $120 \mathrm{~m}$ dpl.; lereng 8\%; semak dan kebun cengkeh; Kec. Sahu } \\
\hline A & $0-14$ & $10 \mathrm{YR} 2 / 2$ & 1.f.sb & Sgt gembur & 40 & 39 & 21 & $\mathrm{~L}$ & 0,84 & 10,9 \\
\hline Bw1 & $14-37$ & 10YR3/2 & 1.f.sb & Gembur & 38 & 45 & 17 & $\mathrm{~L}$ & 0,88 & 10,4 \\
\hline Bw2 & $37-58$ & 10YR3/4 & 1.f.sb & Gembur & 52 & 31 & 17 & $\mathrm{~L}$ & - & \\
\hline Bw3 & $58-94$ & $10 Y R 3 / 4$ & 1.f.sb & Gembur & 66 & 21 & 13 & SL & - & \\
\hline
\end{tabular}

\footnotetext{
${ }^{1)}$ Perkembangan struktur: 1 = lemah; 2 = cukup; ukuran: $\mathrm{f}=$ halus; $\mathrm{m}=$ sedang; bentuk: $\mathrm{sb}=$ gumpal bersudut.

${ }^{2)}$ Kelas tekstur: $\mathrm{L}=$ lempung; $\mathrm{SL}=$ lempung berpasir; $\mathrm{CL}=$ lempung berliat; $\mathrm{SCL}=$ lempung liat berpasir.

${ }^{3)}$ Kadar air $1500 \mathrm{KPa}$ kering udara.
}

Nilai berat isi (BD) tanah umumnya rendah yang bervariasi antara $0.76-0.89 \mathrm{~g} \mathrm{~cm}^{-3}$, kecuali BD pada horison A pedon P1 sebesar $0.96 \mathrm{~g} \mathrm{~cm}^{-3}$. Nilai BD $<0.90 \mathrm{~g} \mathrm{~cm}^{-3}$ memenuhi salah satu persyaratan sifat andik pada kelompok pertama, tetapi tidak menjadi persyaratan pada kelompok kedua dalam Soil Taxonomy (Soil Survey Staff, 2006). BD yang rendah pada Andisols diduga karena tanah mengandung bahan amorf tinggi dengan luas permukaan besar, sehingga menghasilkan ruang pori cukup besar.

\section{Sifat kimia tanah}

Kandungan $\mathrm{C}$ organik tanah umumnya tinggi di horison A dan menurun di horison B secara tidak teratur, keduali pedon P3. Kandungan $\mathrm{C}$ organik di horison A bervariasi antara 3.75-4.65 yang tergolong tinggi. Di horison $\mathrm{B}$, kandungan $\mathrm{C}$ organik berkisar antara 0.44 sampai $4.86 \%$ yang tergolong rendah sampai tinggi (Tabel 2). Penurunan tidak teratur tersebut diduga karena pengendapan dari beberapa kali erupsi.

Nilai $\mathrm{pH}-\mathrm{H} 2 \mathrm{O}$ bervariasi antara 6.0-6.7 di horison A dan antara 6.1-6.8 di horison B. Nilai $\mathrm{pH}-\mathrm{KCl}$ semua pedon lebih rendah dari $\mathrm{pH}_{\mathrm{H} 2 \mathrm{O}}$ yang mencerminkan kompleks adsorpsi tanah bermuatan negatif yang mampu melakukan pertukaran ion-ion. Kisaran $\mathrm{pH}$ tanah-tanah yang relatif tinggi tersebut cukup menguntungkan untuk pertumbuhan tanaman, karena kandungan hara tanah dalam keadaan seimbang (favorable). Nilai $\mathrm{pH}$ yang cukup tinggi tersebut diduga sebagai pengaruh bahan induk yang belum banyak melapuk dan jumlah curah hujan yang relatif tidak terlalu tinggi, sehingga pencucian basa-basa kurang intensif.

Kandungan basa-basa dapat ditukar $(\mathrm{Ca}, \mathrm{Mg}, \mathrm{K}$, $\mathrm{Na})$ bervariasi pada semua pedon dan umumnya didominasi oleh $\mathrm{Ca}$ dan $\mathrm{Mg}$ yang tergolong sedang sampai tinggi. Tingginya kadar $\mathrm{Ca}$ dan $\mathrm{Mg}$ diduga bersumber dari lapukan mineral plagioklas dan piroksen. Sebaliknya, kandungan $\mathrm{K}$ dan Na bervariasi dari rendah sampai sedang. Kondisi tersebut mencerminkan tanah-tanah yang kaya unsur hara dan belum banyak mengalami pencucian dengan $\mathrm{pH}-\mathrm{H}_{2} \mathrm{O}$ tanah cukup tinggi $(\mathrm{pH}>6,0)$ dan kejenuhan basa bervariasi dari sedang sampai tinggi (45-100\%).

Kapasitas tukar kation (KTK) sangat dipengaruhi oleh jenis dan jumlah koloid mineral liat, kandungan 
Tabel 2. Sifat-sifat kimia dari pedon-pedon di daerah penelitian

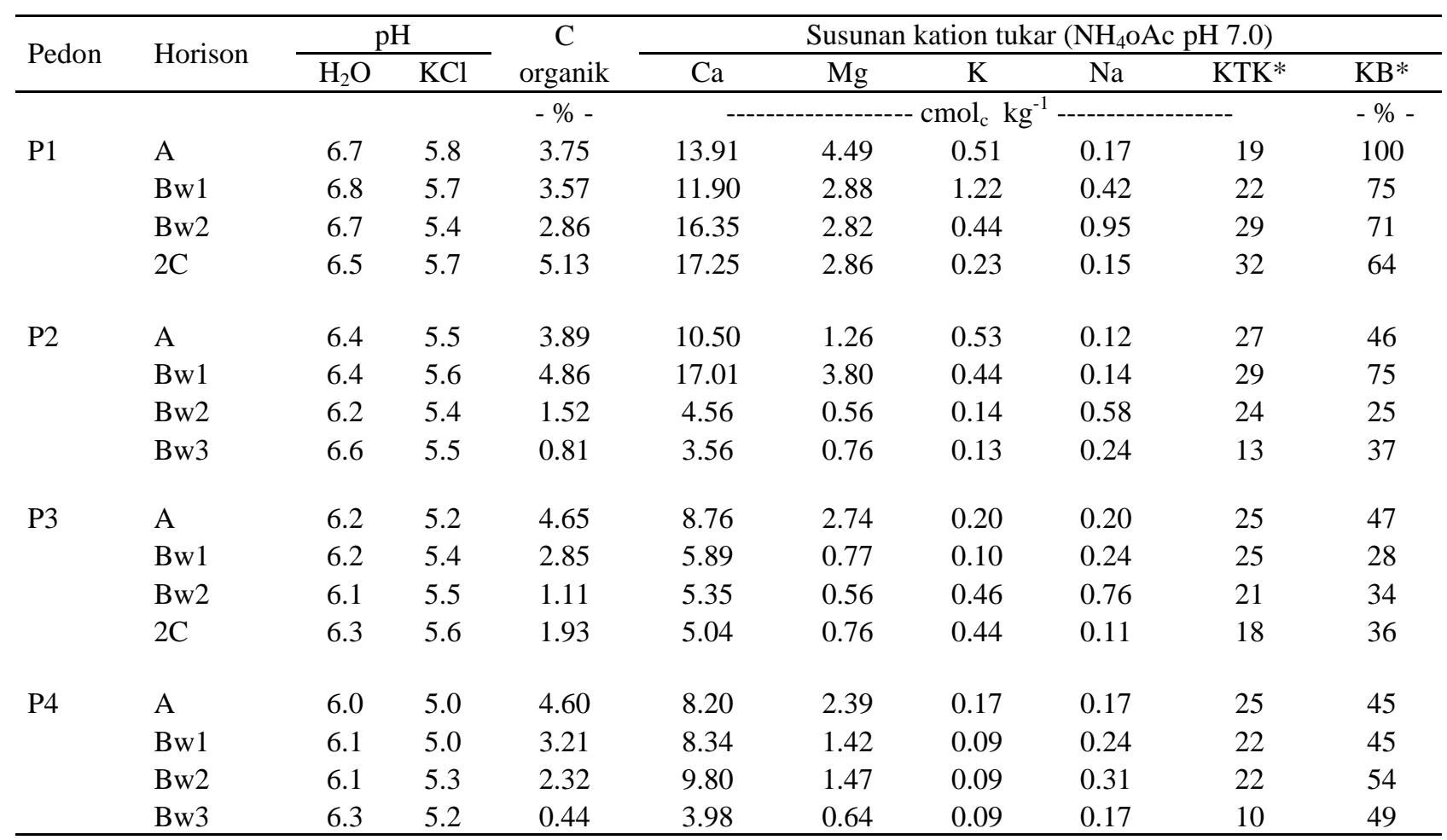

* KTK = kapasitas tukar kation tanah; KB = kejenuhan basa.

liat dan bahan organik. KTK tanah pada semua pedon bervariasi dari rendah $\left(<16 \mathrm{cmol}_{\mathrm{c}} \mathrm{kg}^{-1}\right)$ sampai tinggi $\left(>24 \mathrm{cmol}_{\mathrm{c}} \mathrm{kg}^{-1}\right)$ baik di horison $\mathrm{A}$ maupun B. Rendahnya sebagian KTK tanah mungkin sekali disebabkan oleh kadar bahan organik dan kadar liat yang rendah.

\section{Sifat andik tanah dan klasifikasi tanah}

Tanah-tanah yang mempunyai sifat andik harus memenuhi semua persyaratan dari salah satu kelompok menurut Soil Taxonomy (Soil Survey Staff, 2006) seperti berikut. Kelompok pertama adalah tanah yang mempunyai: (a) kadar $\mathrm{C}$ organik $<25 \%$, (b) $\mathrm{BD} \leq 0.90 \mathrm{~g} \mathrm{~cm}^{-3}$ pada retensi $33 \mathrm{kPa}$, (c) retensi $\mathrm{P} \geq 85 \%$, dan (d) kadar $\left(\mathrm{Al}_{\mathrm{o}}+0.5 \mathrm{Fe}_{\mathrm{o}}\right) \geq$ $2.0 \%$. Kelompok kedua adalah tanah yang mempunyai: (a) kadar $\mathrm{C}$ organik $<25 \%$, (b) kadar fraksi pasir $\geq 30 \%$, (c) retensi $\mathrm{P} \geq 25 \%$, (d) kadar $\left(\mathrm{Al}_{\mathrm{o}}+0.5 \mathrm{Fe}_{\mathrm{o}}\right) \geq 0.4 \%$; (e) kadar gelas volkan $\geq 5$ $\%$, dan (f) nilai indeks $\left[\left(\mathrm{Al}_{\mathrm{o}}+0.5 \mathrm{Fe}_{\mathrm{o}}\right) \times 15.625\right]+$ $[\%$ gelas volkan $] \geq 36.25$.

Data pada Tabel 3 menunjukkan semua pedon mempunyai nilai retensi $\mathrm{P}<85 \%$ tetapi $>25 \%$, yang memenuhi salah satu persyaratan sifat andik kelompok kedua. Retensi P tanah yang cukup tinggi berhubungan erat dengan kadar bahan amorf tinggi yang mampu memfiksasi fosfat, sehingga hara $\mathrm{P}$ menjadi kurang tersedia bagi tanaman. Hal ini menjadi masalah pada tanah Andisols yang dimanfaatkan untuk lahan pertanian (Van Ranst et al., 2004).

Kadar $\mathrm{Al}_{\mathrm{o}}$ pada semua pedon cukup tinggi (2.47 $-5.43 \%$ ), sedangkan kadar $\mathrm{Fe}_{\mathrm{o}}$ lebih rendah dari kadar $\mathrm{Al}_{\mathrm{o}}$ yang bervariasi antara 0.80-2.03\%. Kadar $\left(\mathrm{Al}_{0}+0.5 \mathrm{Fe}_{\mathrm{o}}\right)$ bervariasi antara 2.91-6.39\% yang memenuhi salah satu persyaratan sifat andik, baik kelompok pertama maupun kedua.Tingginya kadar $\mathrm{Al}_{\mathrm{o}}$ dan $\mathrm{Fe}_{\mathrm{o}}$ mencerminkan tingginya kadar bahan amorf.

Kadar gelas volkan untuk persyaratan butir e dari persyaratan kelompok kedua ternyata cukup tinggi untuk semua pedon dengan variasi antara 20$46 \%$ (Tabel 3). Demikian juga, indeks sifat andik untuk butir $\mathrm{f}$ pada persyaratan kelompok kedua nilainya cukup tinggi untuk semua pedon, yang bervariasi antara 73-136.

Meskipun $\mathrm{pH}-\mathrm{NaF}$ tidak digunakan sebagai variabel penentu sifat andik karena digantikan oleh kadar $\left(\mathrm{Al}_{\mathrm{o}}+0.5 \mathrm{Fe}_{\mathrm{o}}\right)$, namun dapat digunakan sebagai indikator tanah-tanah mengandung bahan amorf tinggi. Data pada Tabel 3 menunjukkan bahwa $\mathrm{pH}-\mathrm{NaF}$ dari semua pedon nilainya cukup tinggi (pH-NaF 10.78-10.95), yang memperkuat dugaan bahwa tanah-tanah tersebut mengandung bahan amorf tinggi. Hubungan antara retensi $\mathrm{P}$ dengan 


\section{HIKMATULLAH}

Tabel 3. Sifat-sifat andik tanah pada pedon-pedon di daerah penelitian

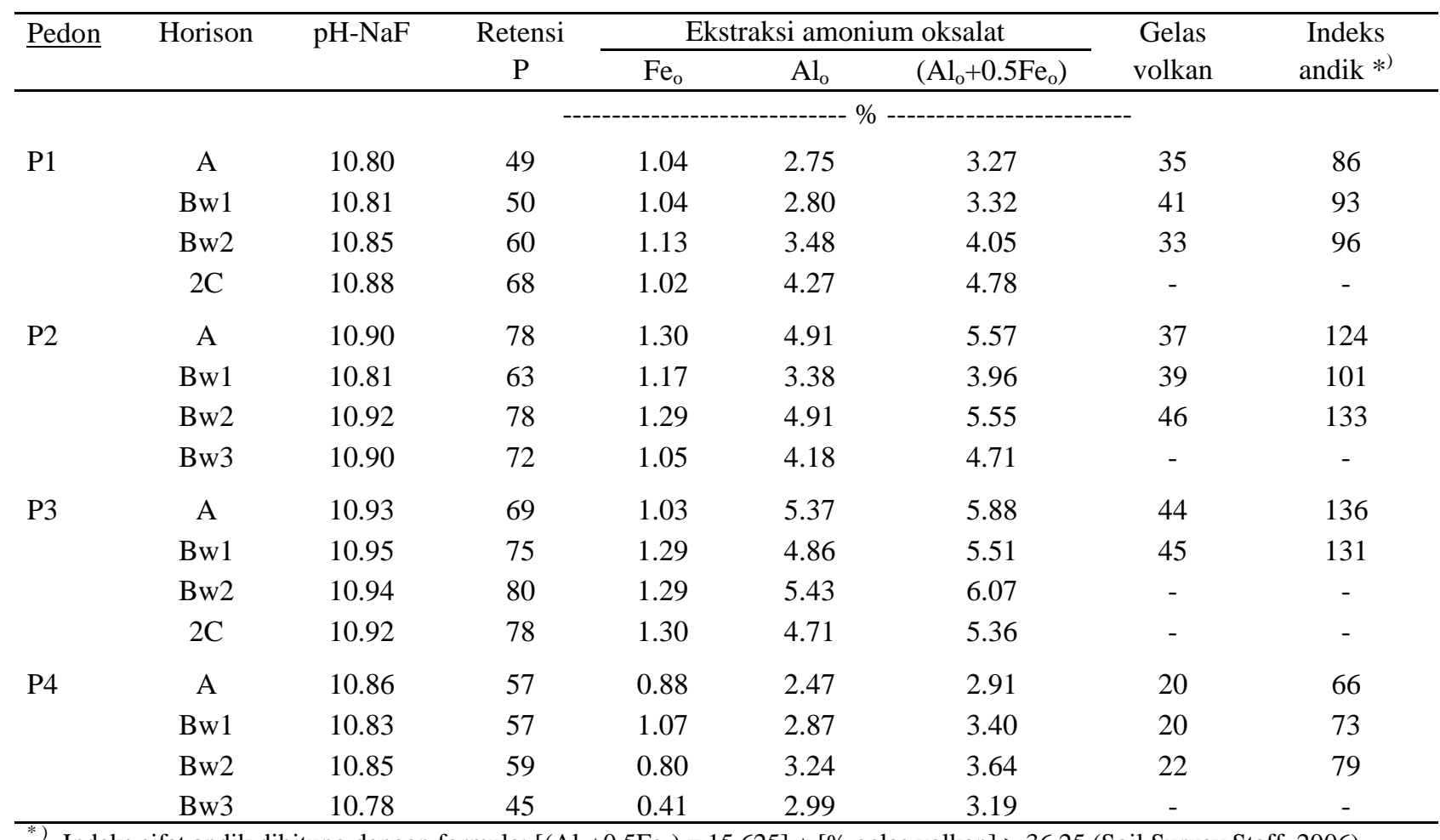

Indeks sifat andik dihitung dengan formula: $\left[\left(\mathrm{Al}_{0}+0.5 \mathrm{Fe}_{\mathrm{o}}\right)\right.$ x 15.625] + [\% gelas volkan] $\geq 36.25$ (Soil Survey Staff, 2006).

kadar $\mathrm{Al}_{\mathrm{o}}, \mathrm{Fe}_{\mathrm{o}},\left(\mathrm{Al}_{\mathrm{o}}+0.5 \mathrm{Fe}_{\mathrm{o}}\right)$ dan $\mathrm{pH}_{\mathrm{NaF}}$ bersifat positif, dengan nilai koefisien determinasi $\left(\mathrm{r}^{2}\right)$ berturut-turut 0.81, 0.53, 0.84 dan 0.84 (Gambar 3).

Berdasarkan persyaratan sifat-sifat andik tersebut, maka keempat pedon memenuhi semua persyaratan sifat-sifat andik pada kelompok kedua, sehingga dapat diklasifikasikan sebagai ordo Andisols. Demikian juga, retensi air pada $1500 \mathrm{kPa}$ pada kondisi kering udara semua pedon $<15 \%$ (Tabel 1) sedangkan pada kondisi tidak kering udara diasumsikan $<30 \%$, maka rejim kelembaban tanah keempat pedon termasuk udik. Pedon P1 dan P2 mempunyai epipedon molik, sedangkan pedon P3 dan P4 mempunyai epipedon umbrik. Dengan demikian keempat pedon dapat diklasifikasikan kedalam subgrup Humic Udivitrands.

\section{Komposisi mineral fraksi pasir}

Komposisi mineral fraksi pasir total keempat pedon menunjukkan komposisi yang relatif sama dengan jumlah berbeda (Tabel 4). Umumnya didominasi oleh gelas volkanik dan mineral mudah lapuk lainnya dari kelompok plagioklas intermedier (labradorit, andesin dan bitownit), dan kelompok piroksen (augit dan hiperstin). Mineral opak dan kuarsa yang merupakan mineral resisten jumlahnya sedikit dengan variasi masing-masing 5-14 \% dan 1 $-22 \%$, yang mencerminkan tingkat pelapukan masih dalam tahap awal. Komposisi mineral dengan asosiasi augit, hiperstin dan labradorit menunjukkan bahan volkan bersifat intermedier.

Jumlah cadangan mineral mudah lapuk termasuk gelas volkan persentasenya masih sangat tinggi, yaitu antara 48-81\%. Dengan demikian cadangan hara tanah cukup tinggi hasil pelapukan mineralmineral tersebut. Tingkat pelapukan relatif (LR) yang diduga dari rasio mineral mudah lapuk (ML) terhadap mineral resisten (MR) menunjukkan sekuen dari yang paling rendah tingkat pelapukannya berturut-turut adalah pedon $\mathrm{P} 1, \mathrm{P} 3, \mathrm{P} 2$, dan $\mathrm{P} 4$.

\section{Implikasi pengelolaan lahan untuk pertanian}

Tanah-tanah volkan muda di daerah penelitian umumnya mempunyai sifat-sifat yang baik. Hal ini dicerminkan oleh penampang cukup dalam, tekstur lempung hingga lempung berpasir dengan konsistensi gembur yang mudah untuk diolah dan baik untuk perkembangan perakaran. Kandungan bahan organik yang tinggi di lapisan atas, $\mathrm{pH}$ tanah $>6.0$ yang merupakan kisaran cukup ideal, dan kandungan kation-kation basa sedang sampai tinggi merupakan sifat-sifat yang sangat menguntungkan dalam 


\section{SIFAT-SIFAT TANAH DARI BAHAN VOLKAN}
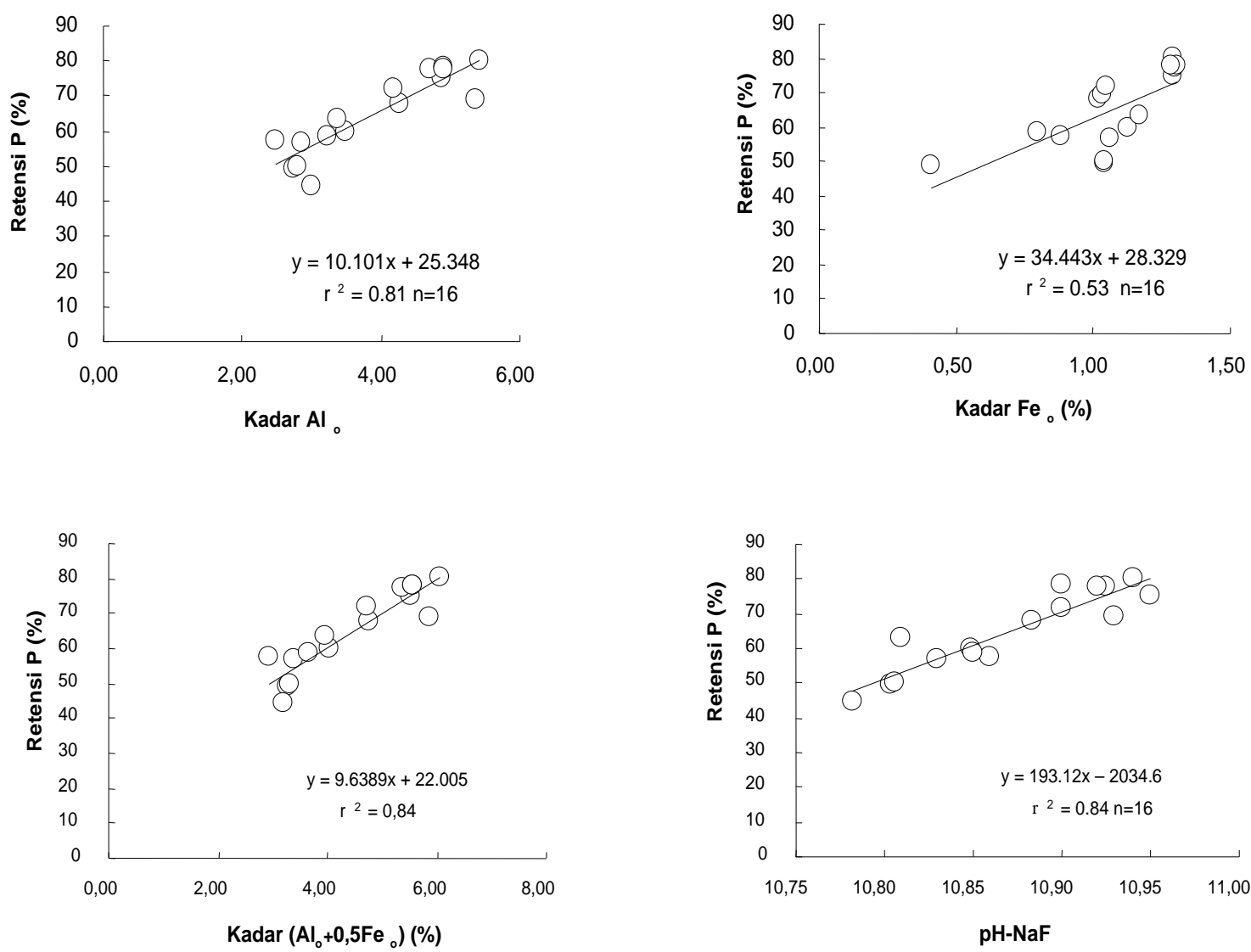

Gambar 3. Hubungan antara kadar $\mathrm{Al}_{0}, \mathrm{Fe}_{0},\left(\mathrm{Al}_{0}+0.5 \mathrm{Fe}_{\mathrm{o}}\right)$ dan $\mathrm{pH}_{\mathrm{NaF}}$ dengan retensi $\mathrm{P}$

Tabel 4. Komposisi mineral fraksi pasir total dari pedon-pedon di daerah penelitian

\begin{tabular}{|c|c|c|c|c|c|c|c|c|c|c|c|c|c|c|c|c|c|}
\hline Pedon & Hor. & Op & $\mathrm{Kk}$ & $\mathrm{Kj}$ & $\mathrm{Li}$ & Lp & $\mathrm{Fb}$ & $\mathrm{Gv}$ & $\mathrm{Ol}$ & An & $\mathrm{La}$ & $\mathrm{Bi}$ & $\mathrm{Au}$ & $\mathrm{Hi}$ & ML & MR & LR \\
\hline \multirow[t]{2}{*}{$\mathrm{P} 1$} & A & 5 & - & - & 1 & 6 & 8 & 45 & - & - & 25 & 2 & 5 & 3 & 80 & 5 & 16.0 \\
\hline & Bw1 & 6 & - & - & 1 & 6 & 3 & 51 & - & - & 21 & 1 & 7 & 4 & 84 & 6 & 14.0 \\
\hline \multirow[t]{3}{*}{$\mathrm{P} 2$} & A & 13 & - & - & 1 & 1 & 6 & 37 & - & - & 25 & 2 & 7 & 8 & 79 & 13 & 6.1 \\
\hline & Bw1 & 15 & - & - & - & - & 6 & 39 & - & - & 27 & - & 4 & 9 & 79 & 15 & 5.3 \\
\hline & Bw2 & 14 & - & 2 & 1 & - & 2 & 46 & - & - & 17 & - & 6 & 12 & 81 & 16 & 5.1 \\
\hline \multirow[t]{2}{*}{ P3 } & A & 10 & - & - & - & - & 9 & 44 & - & - & 16 & 1 & 7 & 13 & 81 & 10 & 8.1 \\
\hline & Bw1 & 12 & - & - & - & 1 & 7 & 45 & - & - & 23 & 1 & 7 & 4 & 80 & 12 & 6.7 \\
\hline \multirow[t]{3}{*}{$\mathrm{P} 4$} & A & 6 & 1 & 4 & 1 & 4 & 25 & 20 & - & 9 & 13 & - & 5 & 12 & 59 & 11 & 5.4 \\
\hline & Bw1 & 7 & 3 & 10 & 2 & 4 & 22 & 20 & 1 & 3 & 10 & - & 5 & 13 & 52 & 20 & 2.6 \\
\hline & $\mathrm{Bw} 2$ & 9 & - & 22 & - & 5 & 6 & 22 & 1 & 3 & 11 & - & 6 & 15 & 58 & 31 & 1.9 \\
\hline
\end{tabular}

Keterangan: $\mathrm{Op}=$ opak; $\mathrm{Kk}=$ kuarsa keruh; $\mathrm{Kj}=$ kuarsa jernih; $\mathrm{Li}=$ limonit; $\mathrm{Lp}=$ lapukan mineral; $\mathrm{Fb}=$ fragmen batuan; $\mathrm{Gv}=$ gelas volkanik; Ol = oligoklas; $\mathrm{An}=$ andesin; $\mathrm{La}=$ labradorit; $\mathrm{Bi}=$ bitownit; $\mathrm{Au}=$ augit; $\mathrm{Hy}=$ hiperstin; $\mathrm{ML}=$ jumlah mineral mudah lapuk, termasuk gelas volkan; MR = jumlah mineral resisten (opak dan kuarsa); dan LR = rasio ML/MR. 
penyediaan hara tanaman.

Selain itu, jumlah cadangan mineral mudah lapuk yang cukup tinggi dapat mendukung penyediaan hara tanah dalam jangka panjang. Masalah yang menonjol adalah kemiringan lereng, yang berpotensi erosi dan longsor terutama untuk lahan yang ditanami tanaman semusim yang secara periodik sering diolah dan permukaan tanah menjadi terbuka. Untuk mengatasi hal tersebut perlu penerapan teknik konservasi tanah yang tepat, seperti teras atau gulud dan penanaman searah garis kontur. Selain itu, retensi $\mathrm{P}$ yang cukup tinggi merupakan masalah pada tanah-tanah volkan/Andisols karena $\mathrm{P}$ difiksasi dalam kompleks adsorpsi, sehingga mengurangi ketersediaan hara $\mathrm{P}$ dalam tanah pada tanah-tanah yang digunakan untuk pertanian. Oleh karena itu, diperlukan dosis pupuk $\mathrm{P}$ yang lebih banyak. Meningkatkan kandungan bahan organik sangat dianjurkan untuk memelihara dan mempertahankan statusnya yang tinggi dalam tanah dengan memanfaatkan residu tanaman pasca panen.

\section{KESIMPULAN DAN SARAN}

Tanah-tanah volkan yang diteliti mempunyai perkembangan profil yang relatif sama, dan sudah mengalami pelapukan pada tahap awal dengan terbentuknya mineral non kristalin (bahan amorf). Sifat-sifat fisik-kimia dan mineral semua pedon memenuhi persyaratan sifat-sifat andik dan diklasifikasikan kedalam ordo Andisols dan subgrup Humic Udivitrands.

Tanah-tanah volkan di daerah penelitian berkembang dari bahan induk bersifat intermedier. Mineral fraksi pasir didominasi oleh gelas volkan dan mineral mudah lapuk dalam persentase yang tinggi, sebagai cadangan hara tanah yang dapat mensuplai kebutuhan hara tanaman dalam jangka panjang.

Tanah-tanah volkan di daerah penelitian sangat potensial untuk pengembangan pertanian, baik tanaman semusim maupun tanaman tahunan. Pengelolaan pada tanah-tanah tersebut ditekankan pada usaha peningkatan kadar bahan organik dan ketersediaan hara $\mathrm{P}$, serta pencegahan bahaya erosi melalui penerapan teknik konservasi tanah yang tepat.

\section{DAFTAR PUSTAKA}

Alkasuma and R.B. Badayos. 2003. The mineralogical characteristics of volcanic soils from North Lampung Sumatra Indonesia. Indonesian Soil and Climate J. 21: 56-68.

Arifin, M., dan S. Hardjowigeno. 1997. Pedogenesis Andisols berbahan induk volkan andesitda basalt pada beberapa zone agroklimat di daerah perkebunan teh, Jawa Barat. In: Subagjo et al. (Eds). Pros. Kongres Nasional VI HITI. Buku II. Himpunan Ilmu Tanah Indonesia. pp. 17-32.

Blakemore, L. C., P. L. Searle, and B.K. Daly. 1987. Methods for chemical analysis of soils. N.Z. Soil Bereau Scientific Report 80. N.Z. Soil Bereau, Lower Hutt, New Zealand.

Burt, R. ed. 2004. Soil survey laboratory method manual. Soil Survey Investigation Report No. 42. Version 4. USDA Natural Res. Conserv. Service. National Survey Center.

Buurman, P. 1990. Chemical, Physical, and mineralogical characteristics for the soil data base. Tech. Report No.7, Ver. 2.1. LREPP Part 2. Soil Data Base Management. CSAR, Bogor.

Buytaert, W., J. Deckers and G. Wyseure. 2006. Regional variability of volcanic ash soils in South Ecuador: the relation with parent materials, climate, and land use. Catena 70 (2): 143-154.

Dudal, R., and M. Soepraptohardjo. 1960. Some considerations on the genetic relationship between Latosols and Andosols in Java (Indonesia). Trans. of the $7^{\text {th }}$ Int. Congr. of Soil Sci. IV. Madison, Wisconsin, USA. Vol. 4: 229-237.

Fiantis, D., and E. Van Rast. 1997. Properties of volcanic ash soil from the Merapi and Talamau volcanoes in West Sumatra, Indonesia. In: Subagjo et al. (Eds). Pros. Kongres Nasional VI HITI. Buku II. Himpunan Ilmu Tanah Indonesia. pp. 1-15.

Hikmatullah, Sukarman, Subagjo, H., dan B.H. Prasetyo. 1999. Karakteristik tanah-tanah yang berkembang dari abu volkan muda di Pulau Flores Nusa Tengara Timur. J. Tanah dan Iklim 17: 1-10.

Hikmatullah, H. Subagjo, and B.H. Prasetyo. 2003. Soil properties of the eastern toposequence of Mount Kelimutu, Flores island, East Nusa Tenggara and their potential for agrcultural use. Indonesian J. of Agric. Sci. 4 (1): 1-11.

Hikmatullah. 2008. Andisol dari daerah Tondano Sulawesi Utara: Sifat-sifat dan klasifikasi. J. Tanah Tropika 13: 77-85.

Leamy, M. L. 1984. Andisols of the world. Congr. Int. Volcanic Soils Comm. Vol.13. Univ. Laguna Secr. Publ. pp. 368-387.

Madeira, M., A. Furtado, E. Jeanroy, and A.J. Herbillon. 1994. Andisols of Madeira island (Portugal); characteristics and classification. Geoderma 62: 363-383.

Nieuwenhuyse, A., A.G. Jongmans, N. Van Breemen. 1993. Andisol formation in a Holocene beach ridge plain under the humid tropical climate of the Atlantic coast of Costa Rica. Geoderma 57: 423-442. 


\section{SIFAT-SIFAT TANAH DARI BAHAN VOLKAN}

Nizeyimana, E. 1997. A toposequence of soils derived from volcanic materials in Rwanda: morphological, chemical, and physical properties. Soil Sci. 162: 350360 .

Parfitt, R.L., M. Russel, and G.E. Orbell.1983. Weathering sequence of soils from volcanic ash involving allophane and halloysite New Zealand. Geoderma 29: 41-57.

Prado, B., C. Duwig, C. Hidalgo, D. Gomez, H. Yee, C. Prat, M. Esteves, and J.D. Etchevers. 2007. Characterization, functioning and clasification of two volcanic soil profiles under different land uses in Central Mexico. Geoderma 139: 300-313.

Schmidt, F.H. and J.H.A. Ferguson. 1951. Rainfall types based on wet and dry period ratios for Indonesia and Western New Guinea. Verh. 42. Jaw. Meteo. dan Geofisik. Jakarta.

Shoji, S., and T. Ono. 1978. Physical and chemical properties and clay mineralogy of Andosols from Kitakami, Japan. Soil Sci. 126: 297-312.

Shoji, S., Takahashi, T., Ito, T., Ping, C.L. 1988. Properties and classification of selected volcanic ash soils from Kenai Peninsula, Alaska. Soil Sci. 145: 395-413.

Shoji, S., M. Nanzyo, R.A. Dahlgren. 1993. Volcanic ash soils. Genesis, properties and utilization. Development in Soil Science vol. 21. Elsevier.

Soil Survey Division Staff. 1993. Soil survey manual. USDA Handbook No. 18. Washington DC.

Soil Survey Staff. 2006. Keys to soil taxonomy. $10^{\text {th }}$ ed. Natural Resources Conservation Service. USDA, Washington DC.

Subagyo, H., B.H. Prasetyo, dan A.M. Sudihardjo. 1997. Pedogenesis of soils developed from andesitic volcanic materials at medium altitude in Mount Manglayang, Bandung Area, West Java. AGRIVITA J. on Agric. Sci. 20 (4): 204-219.

Subagyo, H., N. Suharta, dan A.B. Siswanto. 2000. Tanah-tanah pertanian di Indonesia. In: Adimihardja, A. et al. (Eds). Sumberdaya Lahan Indonesia dan Pengelolaannya. Puslit Tanah dan Agroklimat, Badan Litbang Pertanian, Bogor. pp. 21-65.
Sukarman, H. H. Djohar, dan A. Sofyan. 1993. Penentuan kelas ketebalan tutupan abu volkanik Tambora untuk pembeda satuan peta tanah di dataran Soriutu, Kabupaten Dompu, Nusa Tenggara Barat. In: H. Suhardjo et al. $(E d s)$ Pros. Pertemuan Teknis Penelitian Tanah dan Agroklimat, Bogor. pp. 175-184.

Supriatna, R. 1990. Peta geologi lembar Ternate Maluku skala 1:250.000. Puslitbang Geologi, Bandung.

Tan, K.H. 1965. The Andosols in Indonesia. Soil Sci. 99: $375-378$

Tan, K.H. 1998. Andosol. Program Studi Ilmu Tanah. Program Pascasarjana Universitas Sumatera Utara Medan. 75 hal.

Van Schuylenborgh, J. 1957. On the genesis and classification of soils derived from andesitic tuffs under humid tropical conditions. Neth. J. of Agric. Sci. 5: 99-123.

Van Bemmelen, R.W. 1970. The geology of Indonesia. Vol. IA. General geology of Indonesia and adjacent archipelagoes. $2^{\text {nd }}$ ed. Martinus Nijhoff, The Hague, The Netherlands.

Van Ranst, E., S.R. Utami, and J. Shamshuddin. 2002. Andisols on volcanic ash from Java Island, Indonesia: Physico-chemical properties and classification. Soil Sci. 167: 68-79.

Van Ranst, E. S.R. Utami, J. Vanderdeelen, and J. Shamshuddin. 2004. Surface reactivity of Andisols on volcanic ash along Sunda arc crossing Java Island, Indonesia. Geoderma 123:193-203.

Van Wambeke, A., P.Hastings, and P. Tolomeo. 1986. New Simulation Model (NSM) for Moisture Regimes. Dep. Agr. Bradfield Hall. Cornell University. NY.

Wada, K., Y. Kakuto, H. Ikawa. 1986. Clay minerals, humus complexes, and classification of four Andepts of Maui Hawaii. Soil Sci Soc. Am. J. 50: 1007-1013.

Yatno, E., dan S. Zauyah. 2008. Properties and management implications of soils formed from volcanic materials in Lembang area, West Java. Indonesian J. of Agric. Sci. 9(2): 44-54. 